\title{
Role of zinc along with ascorbic acid and folic acid during long-term in vitro albumin glycation
}

\author{
Rashmi Santosh Tupe and Vaishali Vilas Agte* \\ Agharkar Research Institute, G. G. Agarkar Road, Pune 411004, India \\ (Received 26 March 2009 - Revised 21 July 2009 - Accepted 3 August 2009 - First published online 23 October 2009)
}

The present study aimed to investigate the role of $\mathrm{Zn}$ alone and in the presence of ascorbic acid (AA) and folic acid (FA) in albumin glycation. Glycation was performed by incubations of bovine serum albumin with glucose at $37^{\circ} \mathrm{C}$ along with $\mathrm{Zn}$, AA or FA separately and $\mathrm{Zn}+\mathrm{AA}$ or $\mathrm{Zn}+\mathrm{FA}$ for $150 \mathrm{~d}$. Glycation-mediated modifications were monitored as fluorescence of advanced glycation endproducts, carbonyl formation, $\beta$ aggregation (thioflavin $\mathrm{T}$ and Congo red dyes), albumin-bound $\mathrm{Zn}$, thiol groups and glycated aggregate's toxicity in HepG2 cells. Zn inhibited glycation and $\beta$ aggregation, probably due to observed higher protein-bound $\mathrm{Zn}$. It also protected protein thiols and increased cell survival. AA and FA enhanced glycation, which was lowered in Zn-co-incubated samples. FA increased albumin-bound $\mathrm{Zn}$ and showed maximum cell survival. Although these results warrant further in vivo investigation, the present data help in the understanding of the interplay of $\mathrm{Zn}$ with micronutrients in albumin glycation.

Ascorbic acid: Bovine serum albumin: Glycation: Folic acid: Zinc

Chronic hyperglycaemia causes the Maillard reaction in which reducing sugars, such as glucose, react non-enzymically with amino groups of proteins through a series of reactions, ultimately forming advanced glycation endproducts (AGE), triggering several non-communicable diseases ${ }^{(1-5)}$. Glycated albumin comprises about $6-15 \%$ of the total albumin in normal individuals and rises to $32-40 \%$ in hyperglycaemia. These modifications affect the properties of albumin in several ways, including altered conformation and consequently altered binding. Diabetes mellitus, liver diseases and nephropathy are just a few disorders in which altered albumin functions have been described ${ }^{(6,7)}$

In diabetes and Alzheimer's disease, an imbalance in the concentration of $\mathrm{Zn}$ and micronutrients is suggested as a causative factor $^{(8-10)}$. Though the antioxidant role of $\mathrm{Zn}$ and ascorbic acid (AA) is well established, there are many contradictory reports on beneficial or deleterious effects of $\mathrm{Zn}$, AA or folic acid (FA) supplementation in Alzheimer's disease and AGE-related diseases ${ }^{(11-13)}$. Our initial experiments have suggested that $\mathrm{Zn}$ may directly inhibit the glycation of bovine serum albumin (BSA). Hence, detailed investigations were carried out to understand the role of $\mathrm{Zn}$ alone and $\mathrm{Zn}$ along with AA and FA in the long-term glycation of BSA.

\section{Experimental methods}

\section{Chemicals}

BSA (fraction V, catalogue no. A-7906, initial fractionation by heat shock, purity $98 \%$ (electrophoresis), remainder mostly globulins and fatty acids depleted), thioflavin $\mathrm{T}$ and Congo-Red were obtained from Sigma Chemical Company (St Louis, MO, USA). AA, FA, $\mathrm{ZnSO}_{4}$, glucose and other chemicals were from Hi-Media (Mumbai, India).

\section{Glycation of bovine serum albumin}

For preparation of glycated BSA samples, five different sets, containing BSA $(10 \mathrm{mg} / \mathrm{ml})$, glucose $(0.5 \mathrm{M})$ in PBS (140 mM-sodium chloride, $2.7 \mathrm{~mm}$-potassium chloride, $10 \mathrm{~mm}$-disodium hydrogen phosphate, $1.8 \mathrm{~mm}$-potassium di-hydrogen phosphate, $\mathrm{pH} 7 \cdot 3$ ) were incubated in the dark at $37^{\circ} \mathrm{C}$ for $150 \mathrm{~d}$ in sealed tubes. Before incubation, $\mathrm{Zn}$ $(375 \mu \mathrm{M}), \mathrm{AA}(400 \mu \mathrm{M})$ and FA $(270 \mu \mathrm{M})$ were added to first three sets separately, whereas binary mixtures of $\mathrm{Zn}+\mathrm{AA}$ and $\mathrm{Zn}+\mathrm{FA}$ were added in the fourth and fifth set, respectively. Reaction mixtures were filtered through $0.22 \mu \mathrm{m}$ Millipore membrane filters (Millipore Corp., Billerica, MA, USA) into sterile plastic-capped vials to maintain sterility. After the incubation period, it was ensured that all the solutions were free of microbiological contamination. All the experiments were performed in triplicate and appropriate controls (only BSA, BSA + glucose, i.e. sets no. 6 and 7) were maintained under similar conditions.

After incubation, the reaction mixtures were extensively dialysed against distilled water and stored at $4{ }^{\circ} \mathrm{C}$ for subsequent experiments. The final volumes of the dialysates were made to $3 \mathrm{ml}$ and the protein concentrations were determined by Lowry's method.

Abbreviations: AA, ascorbic acid; AGE, advanced glycation endproducts; BSA, bovine serum albumin; FA, folic acid; HbA1c, glycosylated Hb; MTT, 3-[4,5-dimethylthiazol-2-yl]-2,5-diphenyltetrazolium bromide.

* Corresponding author: Dr Vaishali V. Agte, fax +91020 25651542, email vaishaliagte@hotmail.com 


\section{Quantification of advanced glycation endproducts}

The relative degree of glycation was assessed by measuring intrinsic fluorescent signals from AGE using a spectrofluorometer (F-2500; Hitachi, Tokyo, Japan). Emission scans were taken as arbitrary units/mg protein from 400 to $550 \mathrm{~nm}$ (slit, $10 \mathrm{~nm}$ ) with an excitation wavelength of $370 \mathrm{~nm}$ (slit, $10 \mathrm{~nm}$ ) to assess the overall effect of micronutrients on levels of AGE formation with correction for background fluorescence of PBS.

\section{Carbonyl group estimation}

Protein carbonyl groups were estimated by the method of Uchida et al. ${ }^{(14)}$. Briefly, $0.5 \mathrm{ml}$ protein samples were mixed with an equal volume of 2,4-dinitrophenylhydrazine (0.1\%) in $2 \mathrm{M}-\mathrm{HCl}$ and incubated at room temperature for $1 \mathrm{~h}$. After incubation, protein was precipitated by $20 \%$ TCA $(0.5 \mathrm{ml})$ and washed three times with $1 \mathrm{ml}$ ethanol + ethyl acetate $(1: 1, v / v)$ mixture. Finally, the precipitate was solubilised in $6 \mathrm{M}$-guanidium hydrochloride and absorbance was read at 365 nm (UV1; Thermo Spectronic Corp., New York, USA). Protein carbonyl concentration was calculated by using the molar extinction coefficient $(\varepsilon 365 \mathrm{~nm}=21$ per $\mathrm{mM}$ per $\mathrm{cm})$. The results were expressed as nmol carbonyls/mg protein.

\section{Thioflavin T assay}

For determination of $\beta$ aggregation, thioflavin $T$, a marker for amyloid cross $\beta$ structure, was used ${ }^{(15)}$. Hence, glycated samples $(100 \mu \mathrm{l})$ were incubated with $32 \mu \mathrm{M}$-thioflavin $\mathrm{T}$ in triplicate. Fluorescence was measured after $1 \mathrm{~h}$ incubation at room temperature. Excitation and emission wavelengths were $435 \mathrm{~nm}$ (slit, $10 \mathrm{~nm}$ ) and $485 \mathrm{~nm}$ (slit, $10 \mathrm{~nm}$ ), respectively, with correction for background signals from buffer without thioflavin $\mathrm{T}$.

\section{Binding of Congo red}

Congo red binding to cross- $\beta$ structure was estimated by measuring absorbance at $530 \mathrm{~nm}$ of amyloid structures ${ }^{(16)}$. For this purpose, glycated samples $(500 \mu \mathrm{l})$ were incubated with $100 \mu \mathrm{l}$ of $100 \mu \mathrm{M}$-Congo red in PBS with $10 \%$ (v/v) ethanol for $20 \mathrm{~min}$ at room temperature. Absorbance was recorded for the Congo red-incubated samples as well as for Congo red background.

\section{Cell-culture assays}

Human hepatocyte carcinoma cell line (HepG2) was kindly provided by $\mathrm{Dr}$ M. S. Patole (National Centre for Cell Sciences, India). HepG2 cells were grown in Eagle's minimum essential medium (MEM; Sigma Chemical Co., St Louis, MO, USA) containing $10 \%$ fetal bovine serum (Sigma Chemical Co.) and incubated in a humidified chamber (85\% humidity) containing $5 \% \quad \mathrm{CO}_{2}$ at $37^{\circ} \mathrm{C}$ in a $\mathrm{CO}_{2}$ incubator (Thermo-Forma, Marietta, $\mathrm{OH}, \mathrm{USA}$ ). Cell viability was indirectly measured as a function of the percentage of 3-[4,5-dimethylthiazol-2-yl]-2,5-diphenyltetrazolium bromide (MTT) reduced.

\section{3-[4,5-Dimethylthiazol-2-yl]-2,5-diphenyltetrazolium bromide} assay

HepG2 cells were seeded onto a ninety-six-well plate (Corning Inc., Corning, NY, USA) at a final cell count of 20000 cells per well. For the assay, MEM containing the glycated samples $(200 \mu \mathrm{l})$ was transferred into each well. After $4 \mathrm{~h}$ incubation at $37^{\circ} \mathrm{C}$, medium was removed and MTT $(150 \mu \mathrm{l} /$ well) was added to each well and the plate was kept in a $\mathrm{CO}_{2}$ incubator for an additional $2-4 \mathrm{~h}$. The cells were lysed by the addition of a lysis solution (50\% dimethylformamide, $20 \%$ SDS, pH 4.7) and were incubated for $1 \mathrm{~h}$. The degree of MTT reduction in each sample was subsequently assessed by measuring absorption at 570 and $630 \mathrm{~nm}$ using a microplate reader (Bio Kinetics EL340; Bio-Tek Instruments, Winooski, VT, USA). The net difference $=\mathrm{A}_{570}-\mathrm{A}_{630}$ was used to express the viability of the cells. Results were expressed as percentage cell viability relative to unglycated control (\% BSA control).

\section{Protein-bound zinc estimation}

To determine the protein-bound $\mathrm{Zn}$ in glycated samples, dialysed samples $(1 \mathrm{ml})$ free of unbound $\mathrm{Zn}$ were digested using concentrated $\mathrm{HNO}_{3}$ for $1 \mathrm{~h}$. The final volume of $3 \mathrm{ml}$ was made with metal-free water (Millipore Q; Billerica, MA, USA) and readings for $\mathrm{Zn}$ were taken on an atomic absorption spectrometer (AA 800; PerkinElmer, Shelton, CT, USA). All determinations were carried out in triplicate and the final result was the mean of three estimations. Values were expressed as $\mu \mathrm{mol}$ bound $\mathrm{Zn} / \mathrm{mg}$ protein.

\section{Protein thiol estimation}

Thiol groups of native or modified BSA were measured according to Ellman's assay ${ }^{(17)}$ using 5,5'-dithiobis(2-nitrobenzoic acid) (DTNB). Briefly, the samples $(3.5 \mathrm{mg} / \mathrm{ml})$ were mixed with $0.05 \mathrm{M}-\mathrm{PBS}(\mathrm{pH} 7.6)$ and incubated for $15 \mathrm{~min}$ with $2.5 \mathrm{~mm}$-DTNB. The absorbance was measured at $410 \mathrm{~nm}$. The free thiol concentration of samples was calculated with the help of a standard curve performed with various native BSA concentrations $(0.8$ to $4 \mathrm{mg} / \mathrm{ml}$, corresponding to $19-96 \mathrm{nmol}$ total thiols).

\section{Statistical analysis}

Statistical analysis was performed in Microsoft Excel (Windows XP version; Microsoft Corp., Redmond, WA, USA). Data were expressed as the mean values and standard deviations of triplicate values. The significance of the results was determined by comparison with positive control glycated samples using one-way ANOVA for all sets of experiments.

\section{Results}

Formation of amyloid albumin in presence of different factors

To determine the modifications in the glycated albumin due to co-incubation with $\mathrm{Zn}$, AA and FA, we measured two different glycation biomarkers.

Advanced glycation endproduct fluorescence. Emission fluorescence scans indicated progressive accumulation of 
AGE in the positive control (BSA + glucose) samples. However, in Zn-co-incubated samples (BSA + glucose $+\mathrm{Zn})$, the overall fluorescence was reduced significantly $(t=15 \cdot 11$; $P<0 \cdot 001)$, indicating lowered glycation as compared with the positive control (Fig. 1(a)). When compared with FA alone, Zn exhibited a significant inhibitory effect $(t=26 \cdot 49$; $P<0.001)$ on the extent of AGE formation during its co-incubation with FA (Fig. 1(b)). A similar accompanying decrease
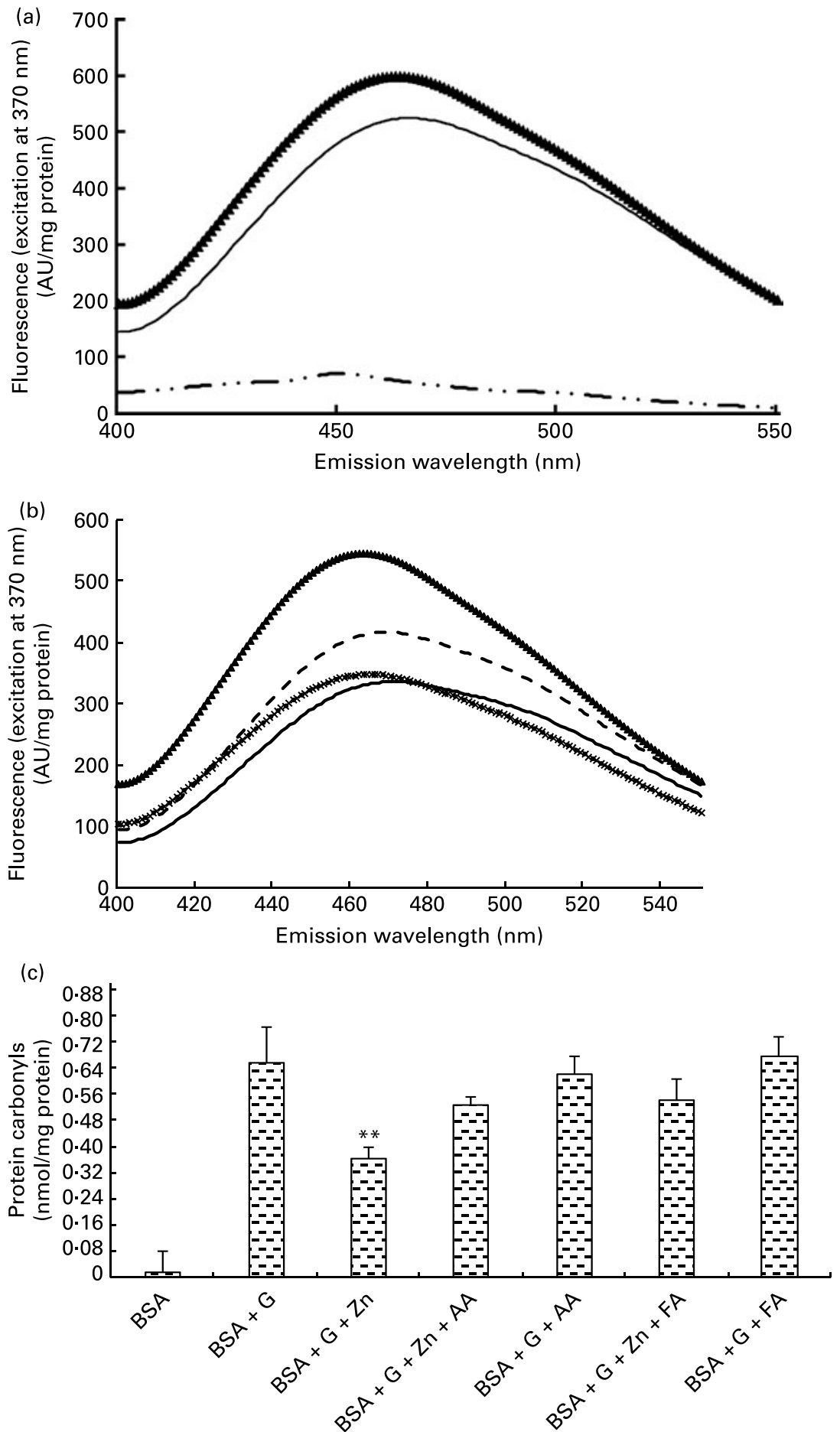

Fig. 1. Glycation of bovine serum albumin (BSA) samples as measured with advanced glycation endproducts (AGE) spectra and protein carbonyl assay. Emission scans from 400 to $550 \mathrm{~nm}$ were taken with an excitation wavelength of $370 \mathrm{~nm}$ for AGE. (a) AGE fluorescence in the presence of Zn along with controls. AU, arbitrary units; $(-\cdots-)$, BSA; $(-\boldsymbol{\Lambda}-)$, BSA + glucose (G) (positive control); (-), BSA $+\mathrm{G}+\mathrm{Zn}$. (b) Spectra of glycated samples by co-incubation of $\mathrm{Zn}$ along with

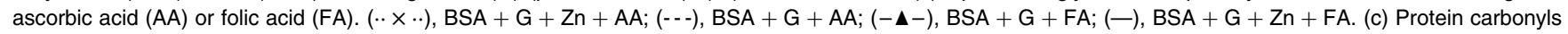
expressed as nmol carbonyls/mg protein. Values are means $(n 3)$, with standard deviations represented by vertical bars. ${ }^{\star \star}$ Mean value was significantly different from that of the BSA $+\mathrm{G}$ treatment (positive control) $(P<0.01$; one-way ANOVA). 
was also observed in $\mathrm{Zn}+$ AA samples as compared with AA samples $(t=17.99 ; P<0 \cdot 001)$ (Fig. 1(b)).

Carbonyl estimation. Since AGE measurement is nonspecific; the carbonyl estimations by the dinitrophenylhydrazine assay are generally used to resolve ambiguities. Results indicated that for the samples incubated with $\mathrm{Zn}$, the protein carbonyls were reduced significantly $(P<0 \cdot 01)$. Zn showed a marginally significant decrease $(P>0.05)$ when incubated along with AA and FA (Fig. 1(c)). The difference in the results of $\mathrm{AGE}$ and dinitrophenylhydrazine assays (for Zn-co-incubated AA or FA samples) could be attributed to the different specificity in these two measurements.

\section{Albumin advanced glycation endproduct condensates as $\beta$-fibrils during glycation}

We determined the level of $\beta$ aggregation of BSA in the presence of various factors using thioflavin $\mathrm{T}$, a fluorescent dye that specifically binds with fibrous structures (Fig. 2(a)). $\beta$ Aggregates formed were significantly different between the treatments as shown by one-way ANOVA $(F=17 \cdot 66$; $P=0 \cdot 001)$. In $\mathrm{Zn}$-co-incubated samples, aggregates were marginally reduced as compared with positive control samples $(P=0 \cdot 08)$. The maximum aggregation occurred in AA-coincubated samples, yet not significantly different from positive control samples. AA + Zn-co-incubated samples showed strong reduction in aggregation, whereas in the presence of FA, $\mathrm{Zn}$ did not show considerable inhibition in $\beta$-sheet formation $(P>0 \cdot 05)$.

To confirm the observation that $\mathrm{Zn}$ inhibits $\beta$-sheet formation of albumin experimentally, Congo red, another $\beta$-sheet-specific dye, was used (Fig. 2(b)). With this assay, the positive albumin control exhibited the strongest absorbance as expected and all the treatment groups showed significant reduction in absorbance $(F=41.83 ; P<0.001)$. On the other hand, aggregates from Zn-co-incubated albumin samples displayed significantly lower absorbance $(P<0 \cdot 001)$. Samples with FA illustrated lower absorbance that was further reduced slightly with Zn co-incubation. While samples with AA elicited weaker absorbance, the samples with $\mathrm{AA}+\mathrm{Zn}$ had significantly decreased absorbance as compared with AA alone.

Data of thioflavin $\mathrm{T}$ and Congo red together suggest that $\beta$-sheet conformations were prevented by $\mathrm{Zn}$ alone or $\mathrm{Zn}$ in the presence of the two vitamins. One way of explaining
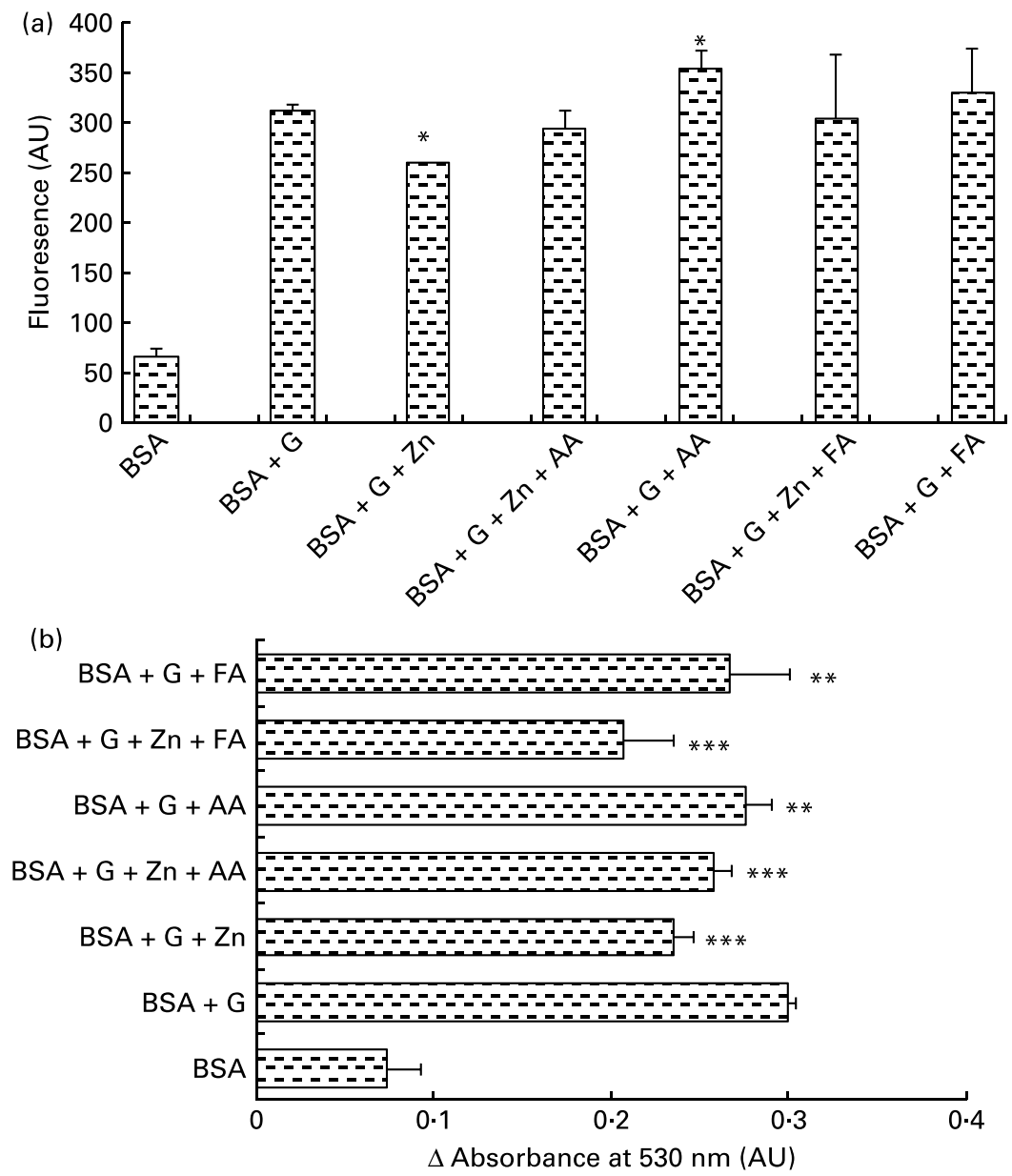

Fig. 2. Transition of amino acid residues to $\beta$-sheet conformation as indicated by amyloid-specific dyes. (a) Effect of $\mathrm{Zn}$ along with ascorbic acid (AA) or folic acid (FA) on thioflavin T fluorescence. AU, arbitrary units; BSA, bovine serum albumin; G, glucose. Values are means ( $n$ 3), with standard deviations represented by vertical bars. * Mean value was marginally significantly different from that of the BSA + G treatment (positive control) $(P=0.08$; one-way ANOVA). (b) Effect of Zn along with $\mathrm{AA}$ or FA on Congo red absorbance at $530 \mathrm{~nm}$. Values are means $(n 3)$, with standard deviations represented by horizontal bars. Mean value was significantly different from that of the BSA $+\mathrm{G}$ treatment (positive control): ${ }^{\star *} P<0.01,{ }^{\star \star *} P<0.001$ (one-way ANOVA). 
these results might be that during the glycation reaction, $\mathrm{Zn}$ prevented the $\beta$-sheet formation in albumin by promoting the native $\alpha$-sheet conformation. The affinities of Congo red and thioflavin T for AA and FA samples were nearly analogous to the positive control. During glycation when $\mathrm{Zn}$ was present along with AA or FA, $\mathrm{Zn}$ could restrain the native conformation that was comparable with glucose $+\mathrm{Zn}$ samples.

\section{Toxicity of aggregates of albumin in HepG2 cells}

We found a greater extent of $\beta$ aggregation in positive control samples, which further showed cytotoxicity and decreased cell viability to $1.05 \%$ (Fig. 3). Zn seemed to have effectively suppressed $\beta$ aggregation, since $54 \%$ of the cells treated by glycated protein co-incubated with $\mathrm{Zn}$ survived after $4 \mathrm{~h}$ incubation $(P<0 \cdot 01)$. With FA alone, only $18 \%$ of cells were viable, but the presence of $\mathrm{Zn}$ along with FA significantly protected cells against the aggregate toxicity $(75 \%$ viability; $P<0.001)$. In contrast to $\mathrm{FA}$, aggregates formed in the presence of AA were less toxic to cells (32\% viability; $P<0.05)$ and co-incubation with $\mathrm{Zn}$ marginally increased cell survival (38\% viability). Overall, against glycationinduced $\beta$-amyloid toxicity, $\mathrm{Zn}+\mathrm{FA}$ treatment exhibited a maximum protective effect in HepG2 cells followed by $\mathrm{Zn}$ alone, though a similar synergistic effect was not manifested by $\mathrm{Zn}+\mathrm{AA}$ samples.

\section{Zinc affinity of albumin modified by different factors}

The unglycated and glycated albumin controls contained about $9 \mu \mathrm{mol}$ bound $\mathrm{Zn} / \mathrm{mg}$ protein (Fig. 4(a)). When $\mathrm{Zn}(375 \mu \mathrm{M})$ was available during glycation, the level of albumin-bound $\mathrm{Zn}$ increased to $11.07 \mu \mathrm{mol} / \mathrm{mg}$ protein $(P<0.001)$ and probably this increased bound $\mathrm{Zn}$ had an attenuating effect on BSA glycation. Parallel to our previous findings ${ }^{(18)}$, maximum albumin-bound $\mathrm{Zn}(11.4 \mu \mathrm{mol} / \mathrm{mg}$ protein; $P<0.001)$ was revealed in $\mathrm{Zn}+\mathrm{FA}$ samples that also elicited the highest cell survival $(75 \%)$. On the other hand, co-incubation of $\mathrm{Zn}$ with AA significantly inhibited $\mathrm{Zn}$ binding to albumin $(8.7 \mu \mathrm{mol} / \mathrm{mg}$ protein), which might be the reason for lower cell survival with $\mathrm{Zn}+\mathrm{AA}$ samples. This inhibitory role of AA on $\mathrm{Zn}$-albumin binding was also observed in AA samples, where bound $\mathrm{Zn}$ was withdrawn, as $\mathrm{Zn}$ levels went down to $5.2 \mu \mathrm{mol} / \mathrm{mg}$ protein compared with controls $(P<0 \cdot 01)$. The correlation between albumin-bound $\mathrm{Zn}$ and cell viability ( $r 0.61 ; P>0.05$ ) indicated a possible role of protein-bound $\mathrm{Zn}$ in reducing aggregate toxicity in HepG2 cells.

\section{Effect of zinc, ascorbic acid and folic acid on protein thiols during glycation}

Albumin is considered as the major source of thiols in plasma. Glycation modifies thiol group(s) to form disulfide bonds and intermolecular aggregates in albumin ${ }^{(19)}$. We therefore examined whether thiol groups were altered under our experimental conditions. In positive control samples, the thiols were significantly decreased by $50 \%$ (Fig. 4(b)). Results indicated a prominent beneficial effect of $\mathrm{Zn}$ for protein thiols $(P<0 \cdot 05)$. AA showed a protective role on thiol group modification with no obvious change in the presence of $\mathrm{Zn}$. FA alone manifested a similar response to AA, but with $\mathrm{Zn}$ it gave very strong shielding from denaturation, as thiol concentrations were almost similar to native BSA $(P<0 \cdot 01)$. These results are on par with other reported studies and collectively suggest that when there is more protein-bound $\mathrm{Zn}$, the thiol groups are less likely to be affected by glycation-induced changes ${ }^{(20,21)}$.

\section{Discussion}

It is known that albumin could be modified by the factors present in its plasma environment. In the present study we have investigated the in vitro modification of BSA by glycation in the presence of $\mathrm{Zn}, \mathrm{AA}$ and FA and their binary combinations. The long-term incubation was performed for maximum induction of $\beta$ aggregation with associated cytotoxicity observations. The present study demonstrates the antiglycation role of $\mathrm{Zn}$, which was additionally influenced by other molecules such as AA and FA.

Several lines of evidence strongly suggest that $\mathrm{Zn}$ being in a single oxidation state of $\mathrm{Zn}^{2+}$ is a redox inert metal and

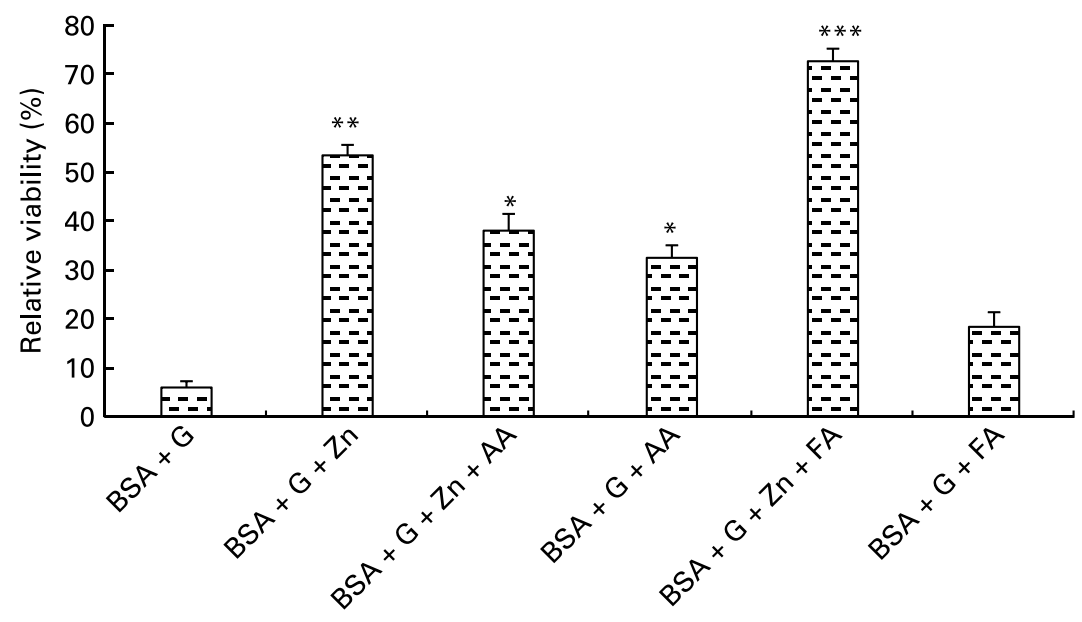

Fig. 3. Effect of $\mathrm{Zn}$ alone or along with ascorbic acid (AA) or folic acid (FA) upon glycated albumin cytotoxicity. The results were expressed as percentage relative viability to the unglycated bovine serum albumin (BSA) control. G, glucose. Values are means ( $n 5-6)$, with standard deviations represented by vertical bars. Mean value was significantly different from that of the BSA $+\mathrm{G}$ treatment (positive control): ${ }^{*} P<0.05,{ }^{\star \star} P<0.01,{ }^{\star \star *} P<0.001$ (one-way ANOVA). 

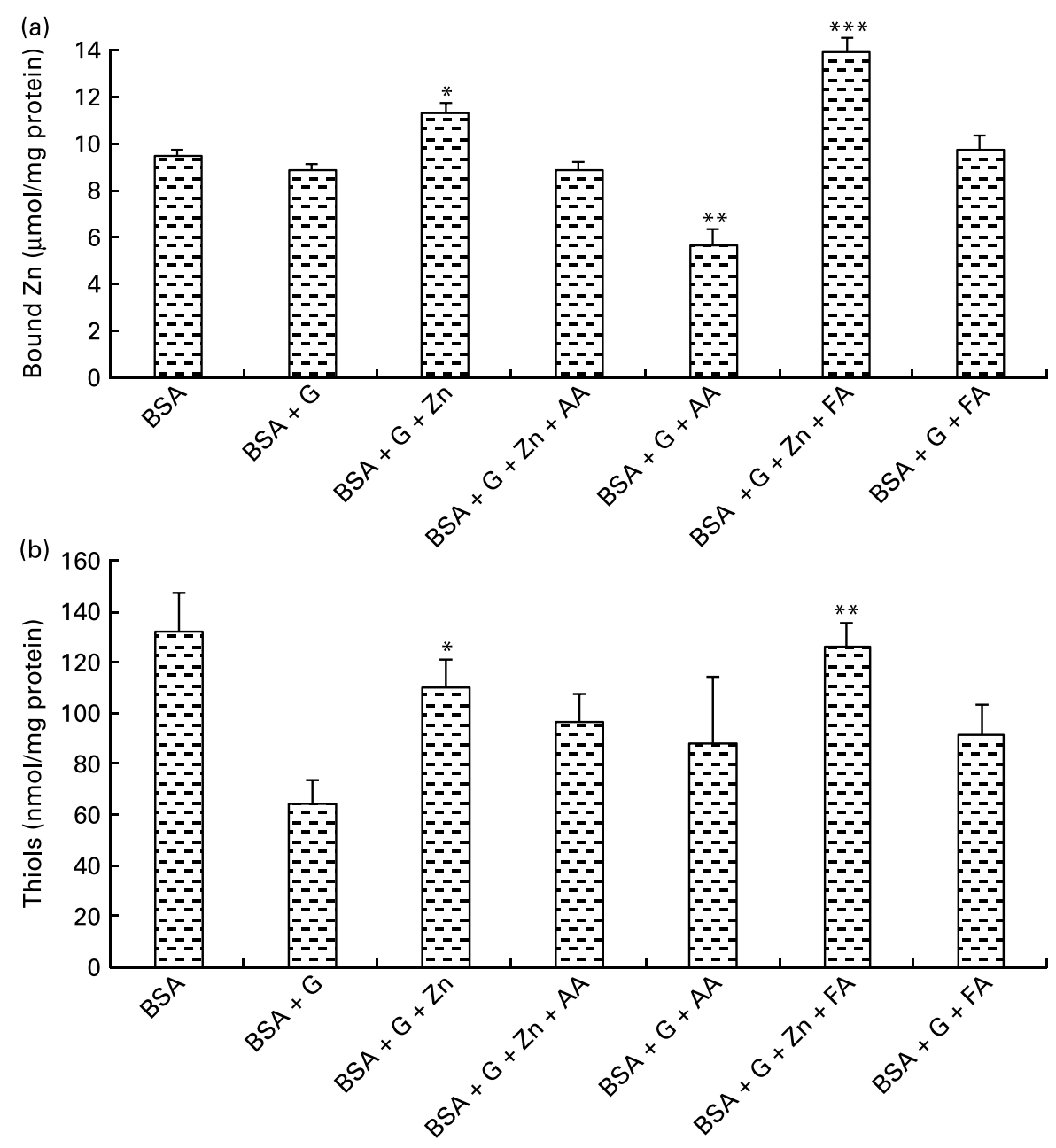

Fig. 4. Effect of different factors on (a) albumin-Zn binding and (b) thiol groups of albumin during glycation. BSA, bovine serum albumin; G, glucose; AA, ascorbic acid; FA, folic acid. Values are means $(n 3)$, with standard deviations represented by vertical bars. Mean value was significantly different from that of the BSA $+G$ treatment (positive control): ${ }^{\star} P<0.05,{ }^{\star \star} P<0.01,{ }^{\star \star \star} P<0.001$ (one-way ANOVA).

hence does not directly participate in oxidation-reduction reactions ${ }^{(22)}$. It is also known to possess an indirect antioxidant property, particularly during protein oxidation ${ }^{(23)}$. In the literature, we find no direct evidence for a role of $\mathrm{Zn}$ in albumin glycation. However, there exists some debate about the role of $\mathrm{Zn}$ in the aetiology of Alzheimer's disease, which is a glycation-induced disease. $\mathrm{Zn}$ has been thought to act as a key mediating factor in Alzheimer's disease pathophysiology as (a) $\mathrm{Zn}^{2+}$ triggers $\mathrm{A} \beta$ aggregation ${ }^{(24,25)}$ and (b) abnormally high levels of $\mathrm{Zn}$ have been found within amyloid deposits in Alzheimer's disease patients ${ }^{(26)}$. Conversely, a protective role of $\mathrm{Zn}$ in amyloid deposition in Alzheimer's disease has also been suggested since (a) $\mathrm{Zn}$ acts as an antioxidant and protects the brain from extensive redox chemical reactions that contribute to Alzheimer's disease-related oxidative stress ${ }^{(27,28)}$ and (b) $\mathrm{Zn}$ supplementation in combination with a low- $\mathrm{Cu}$ diet significantly decreases $(P<0.01)$ amyloid precursor protein expression in platelets ${ }^{(29)}$.

We found reduced $\beta$ aggregation as well as protected thiols in the Zn-containing samples. According to Powell ${ }^{(23)}, \mathrm{Zn}$ protects thiol groups against oxidation, through one of the three mechanisms: (1) direct binding of $\mathrm{Zn}$ to the thiols,
(2) steric hindrance as a result of binding to some other protein site in close proximity to the thiol group or (3) a conformational change from binding to some other site on the protein. Further, during glycation, levels of protein-bound $\mathrm{Zn}$ were sufficiently elevated to decrease $\beta$-amyloid cytotoxicity. Our findings of effective protective action of $\mathrm{Zn}$ in HepG2 cells are in agreement with other reports stating that $\mathrm{Zn}$ protects against the $\mathrm{A} \beta$-generated oxidative stress and related cytotoxicity in primary neuronal cells and human embryonic kidney cells ${ }^{(30,31)}$. There is no direct in vivo evidence about the role of $\mathrm{Zn}$ in albumin glycation; however, there are reports indicating an inhibitory effect of $\mathrm{Zn}$ in the glycation of other proteins. For example, in type 2 diabetic patients, a decrease in glycosylated $\mathrm{Hb}$ (HbAlc) was reported with $\mathrm{Zn}$ supplementation $^{(32)}$. Also, results from our laboratory indicated that low plasma $\mathrm{Zn}$ levels were associated with the formation of cataract with and without diabetes ${ }^{(33,34)}$.

In normal blood plasma, AA is bound to the albumin $(\mathrm{K}=1200 \text { per } \mathrm{M})^{(35)}$. $\mathrm{Zn}$ also binds to albumin $(\mathrm{K}=7.28$ per $\mathrm{M}$ ) where histidine residues are involved. In the covalent attachment of glucose and AA to human serum albumin, participation of histidine residues has been proposed, where 
the modification of histidine groups enhances ascorbatemediated protein fluorophore formation ${ }^{(36)}$. Formation of AA-attributed protein fluorophores might be the reason for the observed increase in AGE fluorescence. With respect to the positive control, there was similarity in protein carbonyl formation and $\beta$ aggregation in AA-co-incubated samples. Second, $\mathrm{Zn}$ binding to albumin was reduced in the presence of AA, which may be due to the competition of AA with $\mathrm{Zn}$ for albumin histidine residues. This explains the lowered cell viability and thiol levels in $\mathrm{Zn}+\mathrm{AA}$ samples as compared with $\mathrm{Zn}$ samples.

During glycation, FA is glycated to form N2-[1-(carboxyethyl)] folic acid, which elucidates higher AGE fluorescence in FA-containing samples. With FA, the protein carbonyls and $\beta$ aggregates formed were similar to the positive control which showed elevated HepG2 toxicity. On the other hand, the addition of FA along with $\mathrm{Zn}$ showed enhanced $\mathrm{Zn}$-albumin binding and the same samples showed maximally protected thiol groups with the highest cell viability. FA has chelation activity and it has been reported previously that the presence of FA causes marked improvement in levels of albuminbound $\mathrm{Zn}^{(18)}$. This increase in albumin-bound $\mathrm{Zn}$ may be offering additional protection to albumin during glycation. This indicates the dual role of FA (in the presence and absence of $\mathrm{Zn}$ ) in albumin glycation. There are reports on beneficial effects of FA supplementation in Alzheimer's disease ${ }^{(37)}$, where Alzheimer plaque formation is shown to be inhibited by FA through detoxification of homocysteine in the liver and kidneys. The present results suggest another protective role of FA other than homocysteine control, in glycation.

The role of micronutrients in albumin glycation is scarcely reported. Only Vinson \& Howard ${ }^{(38)}$ demonstrated an antiglycation role of AA in BSA glycation. In the case of other proteins of physiological importance, AA has been shown to be a potent glycation factor of lens crystallins. AA is known to act as a pentosidine precursor in the glycation reaction and plays an important role in crystallin browning ${ }^{(9,39)}$. Contrasting to these, Krone \& Ely ${ }^{(40)}$ have studied HbA1c in subjects supplemented with up to $20 \mathrm{~g}$ AA daily and found that for each $30 \mu \mathrm{M}$ increase in plasma AA, HbAlc was reduced by approximately $0 \cdot 1 \mathrm{~g} / \mathrm{dl}(1 \mathrm{~g} / \mathrm{l})$. Vitamin C supplementation can decrease insulin glycation and ameliorate aspects of the obesity-diabetes syndrome in ob/ob mice ${ }^{(41)}$. A significant decrease in fasting blood sugar, TAG, LDL, $\mathrm{HbA} 1 \mathrm{c}$ and serum insulin was seen in the group supplemented with $1000 \mathrm{mg}$ vitamin $\mathrm{C}^{(42)}$. Increased levels of homocysteine have been associated with type 2 diabetes and FA is reported to reduce some complications. However, in the case of FA, there are no reports of its direct effects on protein glycation.

To conclude, we found a marked decline in BSA glycation with increased cell viability in the presence of $\mathrm{Zn}$ during long-term incubation. This gives a new dimension to the protective function of $\mathrm{Zn}$ in glycation reactions. In vivo studies relevant to albumin metabolism are hitherto required to further confirm the physiological implications of these in vitro results on the interplay of $\mathrm{Zn}, \mathrm{AA}$ and FA.

\section{Acknowledgements}

R. S. T. received a research fellowship from the University Grants Commission, Government of India.
R. S. T. was involved in data collection, data analysis, data interpretation, the literature search and manuscript preparation. V. V. A. was involved in study design, data analysis, data interpretation, the literature search, manuscript preparation and review of the manuscript.

Both the authors have no financial or commercial conflicts of interest.

\section{References}

1. Singh R, Barden A, Mori T, et al. (2001) Advanced glycation end products: a review. Diabetologia 44, 129-146.

2. Bouma B, Kroon-Batenburg LM, Wu YP, et al. (2003) Glycation induces formation of amyloid cross- $\beta$ structure in albumin. J Biol Chem 278, 41810-41819.

3. Gasic-Milenkovic J, Loske C \& Münch G (2003) Advanced glycation endproducts cause lipid peroxidation in the human neuronal cell line SH-SY5Y. J Alzheimers Dis 5, 25-30.

4. Chibber R, Molinatti PA, Rosatto N, et al. (1997) Toxic action of advanced glycation end products on cultured retinal capillary pericytes and endothelial cells: relevance to diabetic retinopathy. Diabetologia 40, 156-164.

5. Cohen G, Rudnicki M, Walter F, et al. (2001) Glucose-modified proteins modulate essential functions and apoptosis of polymorphonuclear leukocytes. J Am Soc Nephrol 12, 1264-1271.

6. Oettl K \& Staube RE (2007) Review: physiological and pathological changes in the redox state of human serum albumin critically influence its binding properties. Br J Pharmacol 151, 580-590.

7. Sakata N, Moh A \& Takebayashi S (2002) Contribution of superoxide to reduced antioxidant activity of glycoxidative serum albumin. Heart Vessels 17, 22-29.

8. Deibel MA, Ehmann WD \& Markesbery WR (1996) Copper, iron and zinc imbalances in severely degenerated brain regions in Alzheimer's disease: possible relation to oxidative stress. J Neurol Sci 143, 137-142.

9. Fan X, Reneker ME, Obrenovich C, et al. (2006) Vitamin C mediates chemical aging of lens crystallins by the Maillard reaction in a humanized mouse model. Proc Natl Acad Sci U S A 103, 16912-16917.

10. Reynolds EH (2002) Folic acid, ageing, depression and dementia. BMJ 324, 1512-1515.

11. Cuajungco MP \& Faget KY (2003) Zinc takes the center stage: its paradoxical role in Alzheimer's disease. Brain Res Rev 41, $44-56$.

12. Baltz MD, Caspi BE, Glatthaar U, et al. (1984) The failure of ascorbic acid therapy to alter the induction or remission of murine amyloidosis. Clin Exp Immunol 58, 657-662.

13. Morris MC, Evans DA, Schneider JA, et al. (2006) Dietary folate and vitamins B-12 and B-6 not associated with incident Alzheimer's disease. J Alzheimers Dis 9, 435-443.

14. Uchida KM, Kanematsu K, Sakai T, et al. (1998) Protein-bound acrolein: potential markers for oxidative stress (covalent modification of protein/antibody/atherosclerosis). Proc Natl Acad Sci U S A 95, 4882-4887.

15. LeVine H III (1999) Quantification of $\beta$-sheet amyloid fibril structures with thioflavin T. Methods Enzymol 309, 274-284.

16. Klunk WE, Jacob RF \& Mason RP (1999) Quantifying amyloid by Congo red spectral shift assay. Methods Enzymol 309, 285-305.

17. Ellman GL (1959) Tissue sulfhydryl groups. Arch Biochem Biophys 82, 70-77.

18. Agte VV \& Nagmote RV (2004) Study of factors affecting binding of zinc with albumin at physiological zinc concentrations. Biofactors 20, 139-145. 
19. Bourdon E, Loreau N \& Blache D (1999) Glucose and free radicals impair the antioxidant properties of serum albumin. FASEB $J$ 13, 233-244.

20. Fu HW, Moomaw JF, Moomaw CR, et al. (1996) Identification of a cysteine residue essential for activity of protein arnesyltransferase. Cys299 is exposed only upon removal of zinc from the enzyme. J Biol Chem 271, 28541-28548.

21. Griep MA \& Lokey ER (1996) The role of zinc and the reactivity of cysteines in Escherichia coli primase. Biochemistry 35, 8260-8267.

22. Prasad AS, Bao B, Beck FWJ, et al. (2004) Antioxidant effect of zinc in humans. Free Radic Biol Med 37, 1182-1190.

23. Powell SR (2000) The antioxidant properties of zinc. J Nutr 130, $1447 \mathrm{~S}-1454 \mathrm{~S}$.

24. Bush AI, Pettingell WH, Multhaup G, et al. (1994) Rapid induction of Alzheimer A $\beta$ amyloid formation by zinc. Science $\mathbf{2 6 5}$, 1464-1467.

25. Esler WP, Stimson ER, Jennings JM, et al. (1996) Zinc-induced aggregation of human and rat $\beta$-amyloid peptides in vitro. J Neurochem 66, 723-732.

26. Lovell MA, Robertson JD, Teesdale WJ, et al. (1998) Copper, iron and zinc in Alzheimer's disease senile plaques. J Neurol Sci 158, 47-52.

27. Suh SW, Jensen KB, Jensen MS, et al. (2000) Histochemically reactive zinc in amyloid plaques, angiopathy and degenerating neurons of Alzheimer's diseased brains. Brain Res 852, 274-278.

28. Curtain CC, Ali F, Volitakis I, et al. (2001) Alzheimer's disease amyloid- $\beta$ binds copper and zinc to generate an allosterically ordered membrane-penetrating structure containing superoxide dismutase-like subunits. J Biol Chem 276, 20466-20473.

29. Davis CD, Milne DB \& Nielsen FH (2000) Changes in dietary zinc and copper affect zinc-status indicators of postmenopausal women, notably, extracellular superoxide dismutase and amyloid precursor proteins. Am J Clin Nutr 71, 781-788.

30. Cuajungco MP, Goldstein LE, Nunomurai A, et al. (2000) Evidence that the $\beta$-amyloid plaques of Alzheimer's disease represent the redox-silencing and entombment of $\mathrm{A} \beta$ by zinc. J Biol Chem 275, 19439-19442.
31. Yoshiike Y, Tanemura K, Murayama O, et al. (2001) New insights on how metals disrupt amyloid $\beta$ aggregation and their effects on amyloid $\beta$ cytotoxicity. J Biol Chem 276, 32293-32299.

32. Al-Maroof RA \& Al-Sharbatti SS (2006) Serum zinc levels in diabetic patients and effect of zinc supplementation on glycemic control of type 2 diabetics. Saudi Med J 27, 344-350.

33. Agte VV \& Tarwadi KT (2008) Combination of diabetes and cataract worsens the oxidative stress and micronutrient status in Indians. Nutrition 24, 617-624.

34. Tarwadi KT \& Agte VV (2004) Linkages of antioxidant, micronutrient and socioeconomic status with the degree of oxidative stress and lens opacity in Indian cataract patients. Nutrition 20, 261-267.

35. Oelrichs BA, Kratzing CC, Kelly JD, et al. (1984) The binding of ascorbate to bovine serum albumin. Int J Vitam Nutr Res $\mathbf{5 4}$ $61-64$.

36. Hunt JV \& Wolff SP (1991) The role of histidine residues in the nonenzymic covalent attachment of glucose and ascorbic acid to protein. Free Radic Res Commun 14, 279-287.

37. Reynolds EH (2002) Folic acid, ageing, depression and dementia. Br Med J 324, 1512-1515.

38. Vinson JA \& Howard TB (1996) Inhibition of protein glycation and advanced glycation end products by ascorbic acid and other vitamins and nutrients. J Nutr Biochem 7, 659-663.

39. Grandhee SK \& Monnier VM (1991) Mechanism of formation of the Maillard protein cross-link pentosidine: glucose, fructose, and ascorbate as pentosidine precursors. J Biol Chem 266, 11649-11653.

40. Krone CA \& Ely JT (2004) Ascorbic acid, glycation, glycohemoglobin and aging. Med Hypotheses 62, 275-279.

41. Abdel-Wahab YH, O'Harte FP, Mooney MH, et al. (2002) Vitamin $\mathrm{C}$ supplementation decreases insulin glycation and improves glucose homeostasis in obese hyperglycemic (ob/ob) mice. Metabolism 51, 514-517.

42. Afkhami-Ardekani M \& Shojaoddiny-Ardekani A (2007) Effect of vitamin $\mathrm{C}$ on blood glucose, serum lipids, serum insulin in type 2 diabetes patients. Indian J Med Res 126, 471-474. 